\title{
Elektronik Ağızdan Ağıza İletişimin Pazarlama Literatüründeki Önemi
}

The Importance of Electronic Word of Mouth in the Marketing

Literature

\author{
Meltem Yetkin ÖZBÜK ${ }^{1}$ \\ Şafak AKSOY2
}

Geliş tarihi: 06.12.2016, Kabul tarihi: 27.01.2017, Basım tarihi: 10.06.2017

\section{Özet}

Bu çalışmanın amacı, elektronik ağızdan ağıza iletişim (E-AAİLT) konusunun pazarlama alanındaki önemini açıklamaktır. Bu amaçla, öncelikle, ağızdan ağıza iletişsim (AAİLT) ve elektronik ağızdan ağıza iletişim (E-AAİLT) süreçleri anlatılmış ve bu süreçler arasındaki farklılıklar ortaya koyulmuştur. Sonrasında, yapılan sistematik bir literatür araştırması ile $\mathrm{H}$ indeksine göre belirlenmiş en iyi pazarlama dergilerinde E-AAİLT konusu ile ilgili yayınlanmış makaleler incelenmiştir. Bunun sonucunda, E-AAILTT’in “online ağızdan ağıza iletişim”, “online yorum” ve "online tavsiye" kelime grupları ile literatürde ifade edildiği görülmüştür. Ayrıca, bu konu ile ilgili ilk makalenin 2000 yılında yayınlandığı ve 2008 yılından sonra yapılan yayınların sayısında hızlı bir artış olduğu belirlenmiştir. Bu araştırma, E-AAİLT konusunun dünü ve bugünü ile ilgili önemli bulgular sunmaktadır.

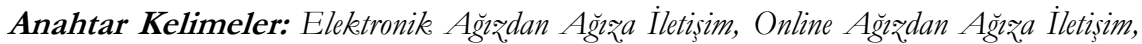
Online Yorum, Online Tavsiye, Literatür Arastirması.

JEL Kodlar1: M31

\begin{abstract}
This study aims to explain the importance of electronic word of mouth (EWOM) in the marketing field. For this purpose, word of mouth (WOM) and electronic word of mouth (E-WOM) processes were explained firstly, and the differences between these processes were revealed. Then, the articles

This study aims to explain the importance of electronic word of mouth (EWOM) in the marketing field. For this purpose, word of mouth (WOM) and electronic word of mouth (E-WOM) processes were explained firstly, and the differences between these processes were revealed. Then, the articles about this topic published in the best marketing journals according to $\mathrm{H}$ index were inspected by a systematic literature review. It was observed that E-WOM is mentioned by "online word of mouth", "online review" and "online recommendation" word groups in the literature. Additionally, the first article was published in 2000 and the

1 Akdeniz Üniversitesi İktisadi ve İdari Bilimler Fakültesi, İşletme Bölümü, Arş. Gör. meltemyetkin@gmail.com

2 Akdeniz Üniversitesi İktisadi ve İdari Bilimler Fakültesi, Isşletme Bölümü, Prof. Dr. safak@akdeniz.edu.tr
\end{abstract}


number of studies about this subject has increased after 2008. This study presents findings about the past and today of the topic.

Keywords: Electronic Word Of Mouth, Online Word Of Mouth, Online Review, Online Recommendation, Literature Review

JEL Codes: M31

\section{Giriş}

Her gün binlerce kişi internette kullandığı ürün ya da hizmetlerle ilgili sayısız yorum yazmaktadır. Bu kişiler, okuduğu kitabı beğenmeyen, yeni aldığ1 ürünün performansindan memnun kalmayan, kaldığ1 otelin temizliğinden şikâyetçi olandan, yediği yemekten çok etkilenen ya da araba seçiminden memnun kalana kadar farklı ürün ve hizmetlerden yararlanan farklı kişilerdir. Diğer tarafta ise bu yazılan yorumları okuyan ve söz konusu ürün, hizmet, marka ya da firmalara yönelik bir tutum oluşturan ve davranışları o yorumlara göre şekillenen kişiler vardır. Bugün ağızdan ağıza iletişim (AAİLT) birbirlerini hiç tanımayan ancak bir firmanın ürün ya da hizmetleri hakkında sayısız yorum yazabilen ve bu yazılanları okuyan kişiler arasında gerçekleşen elektronik ortamdaki bilgi alışverişi haline gelmiştir. Firmalar için internette yazılı olarak kalan ve her geçen gün çoğalan bu yorumlar büyük önem taşımaktadır. 2007 yılında yapılan bir araştırmanın sonuçları, internet kullanıcılarının \%24'ünün bir hizmeti satın almadan önce internetten online yorum okuyarak araştırma yaptığını göstermiştir (Zhu ve Zhang, 2010: 133).

Hayatlarımızda her geçen gün daha çok yer kazanan bu yorumlar ya da elektronik ağıdan ağıza iletişim (E-AAİLT) aslında geleneksel AAİLT'in internet tabanlı platformlar aracılığı ile kitlelere ulaşmasıdır. E- AAİLT ile geleneksel AAILT arasındaki tek fark internetin yer alması gibi görünse de bu farklılık AAİLT'in işleyiş sürecinde önemli bir etki yaratmıştır. Artık firmalar, AAİLT'deki gibi pasif bir rol oynamamakta, bu yorumlarin öneminin farkında olduğu için kişileri online yorum yazmaya teşvik etmekte (Schamari ve Schaefers, 2015; Balagué ve De Valck; De Vries vd., 2012) ve yazılan bu yorumları yöneterek yeni müşteriler kazanmayı ve müşteri kayıplarını önlemeyi amaçlamaktadırlar (Mayzlin, 2006; Xiong ve Bharadwaj, 2014; Van Laer ve De Ruyter, 2010). Bu iletişim türünün mesaj göndericilerini (kaynağını) herhangi bir ürün ya da hizmeti tüketip, bu ürün ya da hizmetten tatmin olan müşteriler (Gounaris vd., 2010; Hsu vd., 2013) ile yaşadıkları tatminsizliği bir an önce kitleler ile paylaşmak isteyen kişiler (De Matos vd., 2012; Gebauer vd., 2013; Lin vd., 2011; Parthasarathy ve Forlani, 2010; Presi vd., 2014) oluşturmaktayken; bu sürecin mesaj alıcılarını yazılan bu yorumlardan yararlanarak ürün ya da hizmetler ile ilgili bir karar vermeye çalışanlar (Gershoff vd., 2003; Häubl ve Trifts, 2000; Senecal vd., 
2005) ve bu yorumlarla ürün, marka ya da hizmet seçen müşteriler (Gupta ve Harris, 2010; Kulkarni vd., 2012; Senecal ve Nantel, 2004) oluşturmaktadırlar.

$\mathrm{Bu}$ çalışma ile pazarlama alanında yer alan bu yeni konunun, EAAİLT’in, gelişimi açıllanmış ve önemine vurgu yapılmıştır. Bu kapsamda, E-AAILLT'in, geleneksel AAİLT'den nasıl farklılaştı̆̆ı gösterilmiş ve literatürde E-AAİLT'in yerine kullanılabilecek farklı ifade şekilleri ile bu konuda yayın yapan dergiler tartışılmıştır. Ayrıca, E-AAİLT'in pazarlama literatüründeki önemine dikkat çekmek amaciyla sistematik bir literatür araştırması yapılmıştır. $\mathrm{Bu}$ araştırmada, ilk olarak pazarlama alanında $\mathrm{H}$ indeksine göre en iyi dergiler belirlenmiş ve bu dergilerde E-AAILT yerine kullanılabilecek kelime gruplarından herhangi birini konusu olarak içeren makaleler tespit edilmiştir. Sonrasında, bu konunun yllar içinde nasıl önem kazandığına dikkat çekilmiş ve sonuç kısmında, bu çalışmanın katkıları ve kısıtlarına değinilip bu konuda çalışmayı düşünen araştırmacılara tavsiyelerde bulunulmuştur.

\section{Ağızdan Ağıza İletişim}

Ağızdan ağıza iletişim (AAİLT), mesaj göndericinin (kaynağın) bir marka, ürün, hizmet ya da hizmet sağlayıcıya yönelik olarak verdiği mesajın, mesaj alıcı tarafindan ticari olarak algılanmadığ1; mesaj gönderici ile mesajı alan kişi arasında gerçekleşen sözlü ve kişiden kişiye olan iletişimdir (Arndt, 1967). Bu sözlü iletişim türü Katz ve Lazarsfeld (1955)'in geliştirdiği iki-aşamalı akış kuramına dayanmaktadır. Bu kurama göre etki, kitle iletişim araçlarıyla düşünce liderlerine ulaşır ve oradan da düşünce liderleri ile iletişim halinde olan bireyler arasında yayılmaktadır. Yani, bilginin akışı iki aşamada gerçekleşmektedir. Ancak, iletişim ve teknolojideki gelişmeler, günümüzde bu kuramda güncellenme yapılmasını gerekli kılmıştır.

Watts ve Dodds (2007), iletişim ve teknolojideki gelişmelerle paralel bir şekilde iki aşamalı akış kuramına dayanarak etkinin ağ modelini geliştirmişlerdir. $\mathrm{Bu}$ model, iki aşamalı akış modelinden iki yönüyle farklılaşmaktadır. İlk olarak, ağ modelinde, etki, iki-aşamalı akış modelinde olduğu gibi sadece düşünce liderlerinden kitlelere ulaşmaz, aynı zamanda bu etki bireylerden de düşünce liderlerine ulaşabilmektedir. İkinci olarak, etkinin sadece bir aşamada değil, birden çok aşamada yayıldığ görülmektedir. Etkinin ya da bilginin yayılımı, ister iki-aşamalı akış kuramına isterse ăg modeline dayansın, araştırmacılar, AAİLT’ $i$ bilginin yayılmasında rol oynayan önemli bir araç olarak görmektedir (Karakaya ve Ganim Barnes, 2010; Lau ve Ng, 2001).

AAİLT, Westbrook (1987:261) tarafindan "belirli bir ürünün ya da hizmetin sahipliği, kullanımı ya da özellikleri ile ilgili ya da satıcısına dair tüketicilere yönelik resmi olmayan iletişimin tümüdür"; Harrison-Walker 
(2001:70) tarafindan ise "ticari-olarak alg1lanmayan, bir mesaj gönderici ile mesaj alıcı arasında gerçekleşen bir marka, ürün, firma ya da hizmet ile ilgili resmi olmayan kişiden kişiye olan iletişimdir" şeklinde tanımlanmaktadır. Bu tanımlarda AAIILT'e dair ortak özellikler dikkat çekmektedir. Öncelikle mesaj, ticari amacı olmayan bir mesaj gönderici(kaynak) tarafindan ya da en azından mesaj alıcı tarafindan ticari olarak algilanmayacak bir mesaj gönderici tarafından gönderilmelidir. Diğer bir ifade ile AAİLT’de, mesaj gönderici ile mesaj alıcı arasında gerçekleşecek iletişim, resmi bir iliş̧iye dayanmamalıdır. Ayrıca kurulacak bu iletişim, bir ürün, hizmet ya da firma ile ilgili bir mesaj verme amacıyla olmalıdır. Mesaj gönderici kişilerin, bu mesajı göndermesinin altında bazı etkenler yatmaktadır.

Mesaj göndericiler, çeşitli motivasyonel etkenler ile AAILLT'de bulunmakta (Dichter, 1996; Sundaram vd., 1998) ve bu durum da mesaj alıcılarda çeşitli etkiler yaratmaktadır. Pazarlama araştırmalarında, AAİLT’in tutum değişikliğinde önemli bir bilgi kaynaği olduğundan bahsedilmektedir (Brown ve Reingen, 1987; Day, 1971). Ayrıca, AAİLT'in tüketici farkındalık ve algilarını (Tsang ve Prendergast, 2009), ürün yargılarını (Bone,1995; Herr vd., 1991) ve satın alma ve seçme davranışlarını (Bansal ve Voyer, 2000; Karakaya ve Ganim Barnes, 2010; Wang, 2011) etkilediği de açıklanmaktadır.

Berger (2014) AAİLT'in tüketici davranış1 üzerindeki etkilerini ikiye ayırmıştır. Birinci etkisi, AAİLT'in tüketicilerde yeni bir ürün ile ilgili farkındalık yaratması ve böylece, o ürüne dair risk-azaltıcı bir mekanizma görevi görmesidir. Özellikle, belirsizliğin fazla olduğu durumlarda AAİLT, kişiler karar verirken risk azaltıcı olarak önemli bir bilgi kaynağı görevi görmektedir. İkincisi ise AAİLT’in tüketici davranışı üzerinde bir ikna gücüne sahip olmasıdır. Diğer bir ifade ile AAIILT ile olumsuz düşünceler kolaylıkla olumluya dönebilir ya da tam tersi yaşanabilir. De Matos ve Rossi (2008)'ye göre AAİLT ile tüketici tatmini, sadakati, bağlllığ1 ve güveni ile tüketicilerin algıladığ1 değer ve kalite artmaktadır. Bughin vd. (2010:113)'e göre ise AAİLT, satın alma kararlarının \%20'si ile \%50'sinin arkasındaki itici güç olmakla beraber kozmetik ve cep telefonu kategorisindeki satıslarda reklamlara göre iki kat daha fazla satış yaratmaktadır.

\section{Elektronik Ağızdan Ağıza İletişim}

20 yllı aşkın bir süredir internet ve internete dayalı teknolojilerdeki gelişmelerin, tüketiciler, firmalar ve pazarlar üzerindeki etkisi pazarlama alanında yeni araştırma alanları açılmasını sağlamıştır (Yadav ve Pavlou, 2014:20). Pazarlama literatüründe yer alan bu yeni konulardan biri ise, 1990'ların sonu 2000'lerin başında internet ve online alışverişin dünya genelinde yaygınlaşması ile araştırmacıların dikkatini çeken ve "elektronik ağızdan ağıza iletişim"(E-AAİLT) olarak isimlendirilen yeni küresel bir ağ 
iletişimidir. E-AAİLT, "bir ürün ya da firma hakkında potansiyel, gerçek ya da önceki müşteriler tarafindan yapılan ve internet aracılı̆̆1 ile çok sayıda kişiye ve kurumlara ulaşabilen herhangi pozitif ya da negatif yorumlardır" (Hennig-Thurau vd., 2004:39).

Yeni teknolojilerin AAİLT açısından tüketiciler üzerindeki etkisi iki yönlüdür. Öncelikle, tüketiciler, interneti kullanarak artık ihtiyaçlarına yönelik daha fazla alternatife ulaşabilmekte ve istedikleri bilgiyi kolay ve hızlı bir şekilde elde edebilmektedirler. Diğer bir ifade ile artık ulaşılmak istenen bilgiye dair her şey bir "tık” yakınlıkta yer almaktadır. Günümüzde en basit ürünlerden en karmaşık olanlara kadar tüketiciler internet ortamında hem firmalardan hem de diğer kullanıcılardan istedikleri bilgilere ulaşabilmektedirler. Aldığı yeni bir telefonu nasıl kullanacağından, rengi solmuş gömleğini eski haline nasıl döndürebileceğine kadar tüketiciler diğer kullanıcıların yorumlarına ve deneyimlerine ulaşabilirler.

Diğer taraftan tüketiciler, internet üzerinde oluşmuş sanal topluluklar aracılığıyla, hiç tanımadığı kişiler ile kendi sosyal ağlarını oluşturabilmekte ve ürün ve hizmetlere yönelik düşüncelerini paylaşabilmektedirler (Dellarocas, 2003:1407). Yaşadıkları kötü ya da güzel deneyimleri, satın aldıkları ürünlerdeki kusurları ya da ürünün fonksiyonlarına dair yorumlarını diğer kullanıcılar ya da firmalara düşüncelerini yazarak iletebilmektedirler. Bu paylaşımlar için günümüzde birçok online perakendeci, tüketici yorumlarının yer aldığı online portallarını oluşturmuşlardır. Böylece, hepsiburada.com ya da n11.com gibi perakendeci web siteleri gerçek tüketici yorumlarının yer aldığ1 çok büyük veri tabanlarına sahiptirler. Tüketiciler artık bu büyük platformlar ya da bloglar, yorum siteleri, sosyal network ağları ve tartışma forumları gibi interaktif internet platformları aracılığıla ürün ya da hizmetlere ilişkin düşüncelerini ve yorumlarını büyük kitleler ile paylaşabilmektedirler (King vd.,2014:167; Kotler ve Keller, 2012:568; Schamari ve Schaefers, 2015:20).

Her ne kadar hem geleneksel AAİLT'de hem de E-AAİLT'de iletilen mesaj tüketicilerin ürün ya da hizmetlere yönelik değerlendirmeleri olsa da bu iki iletişim türü arasında farklılıklar vardır. AAILT ve E-AAİLT arasındaki farklılıklar Lopez ve Sicilia (2014:30)'nın çalışmasında yer alan Şekil 1'deki karşılaştırmanın bileşenlerine göre açıklanmıştır. Bu karşılaştırmada yer alan en önemli fark E-AAİLT'in internete dayalı bir aracı ile gerçekleşmesi ve E-AAİLT'de mesaj alıcının mesaj göndericiye doğrudan geri bildiriminin olmamasıdır. Aşağıdaki alt başlıklarda, Şekil 1'de yer alan modelin bileşenlerine göre AAILT ve E-AAILT arasındaki farklar açıklanmış ve bu bileşenlerin, E-AAİLT'deki öneminden bahsedilmiştir. 


\section{Şekil 1. Ağızdan Ağıza İletişim (AAİLT) ve Elektronik Ağızdan Ağıza İletişim (E-AAİLT) Süreçleri}

AAİT
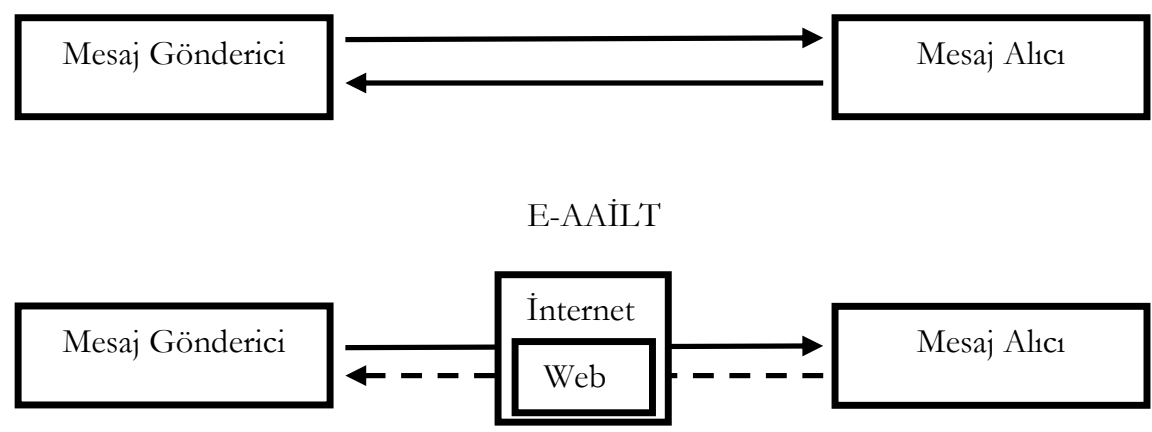

Kaynak: Lopezve Sicilia (2014:30)

\subsection{Mesaj Göndericiler}

\section{1.a. Mesaj Gönderici ile Mesaj Alıcı Arasındaki İlişki}

Geleneksel AAİLT'de, mesaj gönderici başka bir kişi ile belirli bir ürüne yönelik düşüncelerini paylaşmadan önce o kişiyi iyi tanımış olmalı ve o kişiye güvenmelidir. Aslında AAİLT, birbirlerini tanıyan ve çoğu zaman güvenen akraba ya da arkadaş gibi kişiler ya da küçük gruplar arasında gerçekleşen ve bilgi paylaşımını sağlayan bir süreçtir (Dellarocas, 2003:1407; Steffes ve Burgee, 2009:43). Bu sebeple, geleneksel AAİLT, belirli sosyal ilişkileri olan tüketiciler arasında gerçekleşmektedir. Buna karşlık, E-AAILLT'de mesaj göndericiler, isimleri çoğu zaman gizli olan, takma isimlerle düşüncelerini paylaşan ve mesaj alıcının çoğunlukla hiçbir ilişsi kurmadığı kişiler olmaktadırlar (Park,2007:127). Geleneksel AAİLT için çoğu zaman aynı mekan ve zamanda, anlık ve samimi bir iletişim gerekmekteyken, E-AAİLT' de bilgi alışverişinde bulunacak kişiler farklı yer ve zamanlarda bunu gerçekleştirebilmektedirler (Park vd.,2007:127; Steffes ve Burgee, 2009: 43).

\section{1.b. Bilgi Paylaşımının Zamanlaması}

Mesaj göndericiler açısından bilgi paylaşımının zamanlaması konusunda da AAİLT ile E-AAİLT arasında farklılıklar vardır. Geleneksel AAİLT'de tüketiciler herhangi bir ürün ya da hizmetle ilgili bir deneyim yaşadıktan belirli bir süre sonra bu deneyimlerine dair düşüncelerini diğer kişiler ile paylaşabilmektedirler. Diğer bir ifadeyle, bilgi paylaşımı aradan zaman geçtikten sonra olmaktadır. E-AAİLT'de ise bu bilgi paylaşımı çoğu zaman ürün ya hizmet deneyiminden hemen sonra (Berger ve Schwartz, 2011) ve hatta ürün tüketiciye ulaşır ulaşmaz ya da hizmeti deneyimlerken 
olabilmektedir. Örneğin, internetten telefon siparişi veren tüketici telefonuyla ilgili hislerini kargosunu açar açmaz yazabilmekte ya da restoranda yemek siparişi veren bir kişi yemeğinin yarısında o yemeğin fotoğrafinı çekip düşüncelerini internette paylaşabilmektedir.

\section{1.c. Mesaj Gönderme Sebepleri}

E-AAIILT konusundaki çalışmalarda, geleneksel AAİLT'e benzer şekilde, mesaj göndericilerin düşüncelerini paylaşmasının ardında yatan sebepler ve hangi durumlarda yorum yazdıkları araştırmacılar tarafından çalışılmıştır. Tüketicileri online yorum yazmaya yönelten motivasyonlar açıklanmaya çalışılmış (Baldus vd., 2015; Teichmann vd., 2015) ve bu durumun arkasındaki psikolojik ve sosyal etmenler tespit edilmiştir (Alexandrov vd., 2013; Lovett vd., 2013). Ayrıca, kültürel farklllıkların tüketicilerin online yorum yazma davranışlarındaki etkisi tartışılmıştır (Fong ve Burton, 2008; Huggins, Holloway ve White, 2013; Yun, Park ve Ha, 2008). Tatminsizliğin olumsuz yorumların yazılmasında çok önemli bir etkisi olduğu ortaya koyulmuş (De Matos vd., 2012; Gebauer vd., 2013; Lin vd., 2011; Parthasarathy ve Forlani, 2010; Presi vd., 2014) ve tam tersi bir şekilde ise tatminin olumlu yorumların yazılması üzerinde etkisi olduğu gösterilmiştir (Gounaris vd., 2010; Hsu vd., 2013).

\subsection{Mesaj Alıcilar}

\section{2.a. Mesaj Alıcıların Sayısı}

AAİLT'de mesaj gönderici tek seferde bir ya da birkaç mesaj alıcıya düşüncesini iletebilmektedir. Ancak, E-AAİLT'de, mesaj göndericinin ilettiği tek bir mesajı, çok fazla sayıda mesaj alıcı okuyabilmektedir (Park vd., 2007:127). Bu durumda, mesaj gönderici, AAİLT'de, mesaj alıcıya, ürün ya da hizmetlere yönelik düşüncelerini doğrudan iletebilmekteyken EAAILLT'de mesaj alıcı kendi isteği ile mesaj göndericinin ürün ya da hizmete yönelik yorumlarını okumaktadır.

\section{2.b. Erişilebilirlik}

E-AAIILT'i, mesaj alıcılar açısından AAİLT'den farklı kılan bir diğer sebep ise erişebilirliktir. E-AAİLT'de paylaşılan yorumlar, kalıc1, kolay erişilebilir ve kamuya açık bir alanda kayıtlı olduğu için (Dellarocas vd., 2007), mesaj alıcılar, istedikleri zaman ve mekanda, istedikleri miktarda bilgiye, istedikleri sayıda kaynaktan kolayca erişebilmektedirler (Chatterjee, 2001:5). Ancak, AAİLT'de, mesaj alıcılar, bilgiye ulaşmak için mesaj gönderici ile aynı anda ve aynı mekanda bulunmalıdırlar ve mesaj göndericinin $\mathrm{o}$ anda paylaştığı bilgi miktarı ölçüsünde kaynaktan yararlanabilmektedirler. 


\section{2.c. Cevap Verebilirlik}

Mesaj gönderici, AAİLT'de mesaj alıcıya bir cevap verebilmekte ve aynı anda karşlıklı bir iletişim halinde olabilmekteyken (Lopez ve Sicilia, 2014: 29), E-AAİLT'de mesaj alıc1, mesaj göndericinin yorumlarına, mesaj1 okuduğu platform izin verirse yanıt verebilmektedir. $\mathrm{Bu}$ yanıt, mesaj göndericinin düşünceleri internette yer aldıktan hemen sonra ya da çok uzun bir zaman geçtikten sonra da verilebilmektedir.

\section{2.d Mesajin Etkileri}

E-AAİLT'in, mesaj1 alan tüketiciler üzerindeki etkisinin AAİLT ile benzerlikler gösterdiği ve tüketicilerin karar verme sürecini etkilediği gösterilmiştir (Gershoff vd., 2003; Häubl ve Trifts, 2000; Senecal vd., 2005). Özellikle tüketiciler, ürün ve marka seçerlerken online yorumları s1klikla okumaktadırlar. Örneğin, Gupta ve Harris (2010) online yorumların bilgi işleme motivasyonu yüksek ve düşük olan tüketicilerdeki ürün seçimi sürecine etkisini göstermişlerdir. Senecal ve Nantel (2004) ise websitesinin ve tavsiye kaynağının türüne göre online yorumların tüketicilerin marka seçimini etkilediğini ortaya koymuşlardır. Kulkarni vd. (2012) ise online değerlendirmelerin otomobil seçme davranışı üzerindeki etkisini incelemişlerdir. Bu çalışmalara ek olarak, online yorumların tüketicilerin satın alma süreci üzerindeki etkileri sıklıkla çalışılmıştır. Bununla ilgili, online yorumun olumlu ya da olumsuz olması ve web sitesinin sayginlığının satın alma niyeti üzerindeki etkisi incelenmiştir (Park ve Lee, 2009). Tanıdık ve tanıdık olmayan markalarla ilgili yapılan yorumlarda olumluluk ya da olumsuzluk açısından bir tutarlilık bulunmasına (Benediktus vd., 2010); ürünün deneyimsel ya da beğenmelik olmasına göre yorumların satın alma davranışına (Park ve Lee,2009; Christodoulides vd., 2012; Zhao vd.,2013; Huang vd., 2009) etkisi incelenmiştir.

\subsection{Arac1 Kanal}

Geleneksel AAİLT'de verilecek mesaj, mesaj göndericiden mesaj alıcıya çoğu zaman sözlü olarak doğrudan ulaşabilmektedir. Ancak, E-AAİLT'de yorumlar, mesaj alıcılara internet tabanlı platformlar aracılığı ile ulaşmaktadır. Bu durumda, ürün ya da hizmetlere yönelik olan kullanıcı yorumları, mesaj alıcılara ulaşmadan önce e-perakendeci ticari bir web sitesinin ya da herhangi bir forum moderatörünün kontrolünden geçmektedir (Park, 2007:127). Bu sebeple, AAİLT ve E-AAİLT'de paylaşılan bilginin içeriği ile ilgili farklılıklar bulunmaktadır. Geleneksel AAİLT'de paylaşılan bilginin içeriği genelde mesaj gönderici ve mesaj alıcı arasındaki ilişki ile belirlenmekte ve bu bilginin ayrıntıları ve samimiyeti bu kişiler arasındaki ilişkinin gücü ile şekillenmektedir. Diğer bir ifade ile bilginin içeriği çoğu zaman bilgi paylaşımının gerçekleştiği ana göre belirlenmektedir. Ancak, E-AAİLT’de içerik çok daha önemlidir ve bu içerik mesaj gönderici tarafından önceden 
tasarlanarak mesaj alıc1/lara iletilir (Berger ve Schwartz,2001) ve bu mesaj1 yayınlayacak platformlardaki kişilerin kontrolünden geçerek internette yayınlanır. Firmalar için bu kontrolün sağlanması önemlidir çünkü bu yorumların olumlu ya da olumsuz oluşuna göre firmaların satışlarının önemli ölçüde etkilendiği görülmüştür (Duan vd.,2008; Chevalier ve Mayzlin, 2006; Chintagunta vd., 2010, Ho-Dac vd., 2013). Bu sebeple, firmalar negatif online yorumlarla ilgilenmek için stratejiler geliştirmektedirler (Van Noort ve Willemsen, 2012). Ayrıca, firmaların yeni ürün geliştirirken (Decker ve Trusov, 2010) ve pazar yapisinin tahmininde (Lee ve Bradlow, 2011; Netzer vd., 2012) online yorumlardan yararlandıkları görülmüştür. Bu sebeple firmaların, tüketicileri online yorum yazmaya teşvik için yeni yöntemler geliştirdikleri görülmektedir (Schamari ve Schaefers, 2015; Jensen, 2008; Balagué ve De Valck; De Vries vd., 2012).

\section{Literatür Araştırması}

E-AAİLT'in pazarlama literatüründeki önemini ortaya koymak amaciyla bu konu ile ilgili sistematik bir literatür araştırması uygun görülmüştür. Öncelikle, pazarlama alanında en iyi olduğu düşünülen, Google AkademikMetrikler, İşletme, İktisat ve Yönetim başlığı, Pazarlama alt başlı̆̆ında yer alan ve 2014 ile 2015 yıllarındaki H5 indeks değerleri en yüksek olan 24 dergi belirlenmiştir. Bu dergilerin isimleri ile 2014 ve 2015 ylllarındaki H5 indeks değerleri Tablo 1'den görülmektedir.

Tablo 1: Google Scholar Pazarlama Alanında Yer Alan En İyi 24 Dergi

\begin{tabular}{rlrr}
\hline \# & Dergi ad & $\begin{array}{r}\text { 2014 H5 } \\
\text { Değeri }\end{array}$ & $\begin{array}{r}\text { 2015 H5 } \\
\text { Değeri }\end{array}$ \\
\hline $\mathbf{1}$ & Journal of Marketing & 58 & 64 \\
\hline $\mathbf{2}$ & Journal of the Academy of Marketing & & \\
& Science & 51 & 51 \\
\hline $\mathbf{3}$ & Journal of Consumer Research & 50 & 59 \\
\hline $\mathbf{4}$ & Journal of International Marketing & 28 & $*$ \\
\hline $\mathbf{5}$ & Journal of Interactive Marketing & 33 & 35 \\
\hline $\mathbf{6}$ & Journal of Advertising & $*$ & 29 \\
\hline $\mathbf{7}$ & Journal of Service Research & 31 & 32 \\
\hline $\mathbf{8}$ & Journal of Marketing Research & 54 & 54 \\
\hline $\mathbf{9}$ & Journal of Consumer Psychology & 35 & 40 \\
\hline $\mathbf{1 0}$ & Marketing Science & 44 & 39 \\
\hline $\mathbf{1 1}$ & Industrial Marketing Management & 56 & 58 \\
\hline $\mathbf{1 2}$ & Journal of Retailing & 32 & 36 \\
\hline $\mathbf{1 3}$ & International Journal of Research in & & \\
& Marketing & 32 & 31 \\
\hline $\mathbf{1 4}$ & Journal of Business Research & 64 & 72 \\
\hline $\mathbf{1 5}$ & International Journal of Consumer & $*$ & 29 \\
\hline & & & 89
\end{tabular}




\begin{tabular}{llrr}
\hline & Studies & & \\
\hline $\mathbf{1 6}$ & Psychology \& Marketing & 33 & 31 \\
\hline $\mathbf{1 7}$ & Managing Service Quality & 28 & $*$ \\
\hline $\mathbf{1 8}$ & European Journal of Marketing & 40 & 42 \\
\hline $\mathbf{1 9}$ & Journal of Services Marketing & 28 & 31 \\
\hline $\mathbf{2 0}$ & Service Industries Journal & 30 & $*$ \\
\hline $\mathbf{2 1}$ & Journal of Retailing and Consumer & 31 & 36 \\
& Services & $*$ & 34 \\
\hline $\mathbf{2 2}$ & Journal of Marketing Management & $*$ & 31 \\
\hline $\mathbf{2 3}$ & International Marketing Review & 28 & $*$ \\
\hline $\mathbf{2 4}$ & Journal of Consumer Marketing & & \\
\hline
\end{tabular}

* İlgili yıla ait olan değerlere ulaşılamamıştır.

Tablo 1'de yer alan dergilerde yayınlanmış makaleler içinde, çalışmanın temel konusu olan "elektronik ağızdan ağıza iletişime (electronic word of mouth)" ek olarak literatürü her yönüyle taramak ve gözden kaçırılmış bir kısım bırakmamak amaciyla, pratikte ve teoride de bu kelimenin yerine kullanılabilen, King vd. (2014:168) tarafindan da belirtilmiş olan, "online ağızdan ağıza iletişim (online word of mouth)", "online yorum (online review)", "online tavsiye (online recommendation)", "online viral pazarlama (online viral marketing)" ve "online fisıltı (online buzz)" kelime gruplar1 kullanılarak arama gerçekleştirilmiştir. 2016 yılı Eylül ayında, Tablo 1'de yer alan 24 dergide, 2015 yılı ve öncesinde yayınlanmış makaleler arasında bu altı kelime grubu kullanilarak yapilan tarama sonucunda bu konu ile ilgili en fazla sayıda makaleye "online ağızdan ağıza iletişim" kelime grubu ile ulaşıldığ görülmektedir. Bunu "online yorum" ve "online tavsiye" kelime gruplar1 ile yapılan tarama sonuçları takip etmektedir. Sonrasında ise "elektronik ağızdan ağıza iletişim", "online viral pazarlama" ve "online fisıltı" bu konuya dair yayınlanmış makalelerde yer alan arama ölçütleri olarak karşımıza çıkmaktadır (Tablo 2).

Tablo 2: Arama Ölçütlerine Göre Makale Sayıları

\begin{tabular}{lr}
\hline Arama Ölçütü & Makale Sayıs \\
\hline online ağızdan ağıza iletişim (online word of mouth) & 191 \\
\hline online yorum (online review) & 144 \\
\hline online tavsiye (online recommendation) & 82 \\
\hline elektronik ağızdan ağıza iletişim (electronic word of mouth) & 52 \\
\hline online viral pazarlama (online viral marketing) & 10 \\
\hline online fisıltı (online buzz) & 3 \\
\hline Toplam & 482 \\
\hline
\end{tabular}




\section{Şekil 2: Arama Ölçütlerine Göre Erişilen Makale Sayıları}

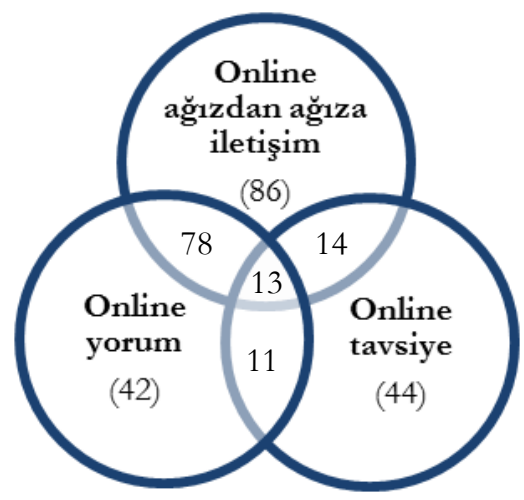

Tablo 2'de yer alan arama ölçütleri kullanılarak toplamda 482 makaleye erişilmiştir. Ancak, bu 482 makalenin eşsiz olmadığı ve bir makaleye birden fazla arama ölçütü ile erişilebildiği görülmüştür. Bunun üzerine, birbiri ile en fazla ilişkili olduğu düşünülen arama ölçütleri tespit edilmiştir. Buna göre, en fazla sayıda makaleye erişilebilen arama ölçütleri olan "online ağızdan ağıza iletişim", "online yorum" ve "online tavsiye" kelime gruplarına göre erişilmiş eşsiz ve ortak makaleler tespit edilmiştir. Sonuçlar, "online ağızdan ağıza iletişim" arama ölçütü ile erişilmiş 191 makalenin, 105'ine "online tavsiye" ya da "online yorum" arama ölçütleri kullanılarak da erişilebildiğini göstermiştir. Bu 105 makalenin 13’ü, "online ağızdan ağıza iletişim”, "online yorum" ya da "online tavsiye" arama ölçütlerinden her hangi biri kullanılarak da erişilebilen makalelerdir (Şekil 2). Sonuç olarak, 482 makalenin 177'si arama ölçütlerine göre ortak makaleler olarak belirlenmiş ve konu ile ilgili 305 özgün makaleye erişilmiştir.

Tablo 3: E-AAİLT Konusu ile İlgili Makalelerin Yer Aldığ1 Dergiler

\begin{tabular}{clr}
\hline \# & Dergi ad & Makale Sayls \\
\hline 1 & Journal of Interactive Marketing & 49 \\
\hline 2 & Journal of Business Research & 37 \\
\hline 3 & Marketing Science & 29 \\
\hline 4 & European Journal of Marketing & 25 \\
\hline 5 & Journal of Marketing Research & 24 \\
\hline 6 & Psychology \& Marketing & 21 \\
\hline 7 & Journal of Retailing & 17 \\
\hline 8 & Journal of Marketing & 13 \\
\hline 9 & International Journal of Research in Marketing & 13 \\
\hline
\end{tabular}




\begin{tabular}{llr}
\hline 10 Journal of Services Marketing & 12 \\
\hline 11 Service Industries Journal & 10 \\
\hline 12 Managing Service Quality & 8 \\
\hline 13 Journal of Consumer Research & 8 \\
\hline $14 \quad$ Journal of Service Research & 7 \\
\hline 15 Journal of the Academy of Marketing Science & 7 \\
\hline $16 \quad$ Journal of Consumer Psychology & 5 \\
\hline 17 Journal of Retailing and Consumer Services & 3 \\
\hline 18 Journal of Advertising & 2 \\
\hline 19 Journal of Marketing Management & 1 \\
\hline 20 International Journal of Consumer Studies & 1 \\
\hline 21 Industrial Marketing Management & 0 \\
\hline 22 International Marketing Review & 305 \\
\hline 23 Journal of Consumer Marketing & \\
\hline 24 & Journal of International Marketing & \\
\hline & Toplam &
\end{tabular}

Bu konu ile ilgili ulaşılan 305 makalenin, Tablo 1 'de yer alan pazarlama dergilerine göre dağılımı incelenmiştir. İnceleme sonucunda, E-AAİLT konusuna dair en fazla sayılda makale yayınlayan derginin 49 makale yayınlamış olan "Journal of Interactive Marketing" olduğu görülmektedir. Bu dergiyi sirasiyla, 37 makale ile "Journal of Business Research", 29 makale ile "Marketing Science", 25 makale ile "European Journal of Marketing" ve 24 makale ile "Journal of Marketing Research" dergileri takip etmektedir (Tablo 3).

Konunun, yıllara göre gelişimine ve önem kazanımına dikkat çekmek için, makale sayısındaki artış ylllara göre incelenmiştir. Şekil 3’te görüldüğü üzere, elektronik ağızdan ağıza iletişim konusu ilk olarak 2000 yılında ele alınmıştır. 2001 yılında bu konuda yayınlanmış makale bulunmazken 2002 yılı ve sonrasında artan bir hızla bu konu araştırmacıların dikkatini çekmiştir. Özellikle, 2010 yllı ve sonrasında E-AAİLT’i konu alan makalelerinin sayısında önemli bir artış görülmektedir. 


\section{Şekil 3: Elektronik Ağızdan Ağıza İletişim Konusunun Yıllara Göre Önemi}

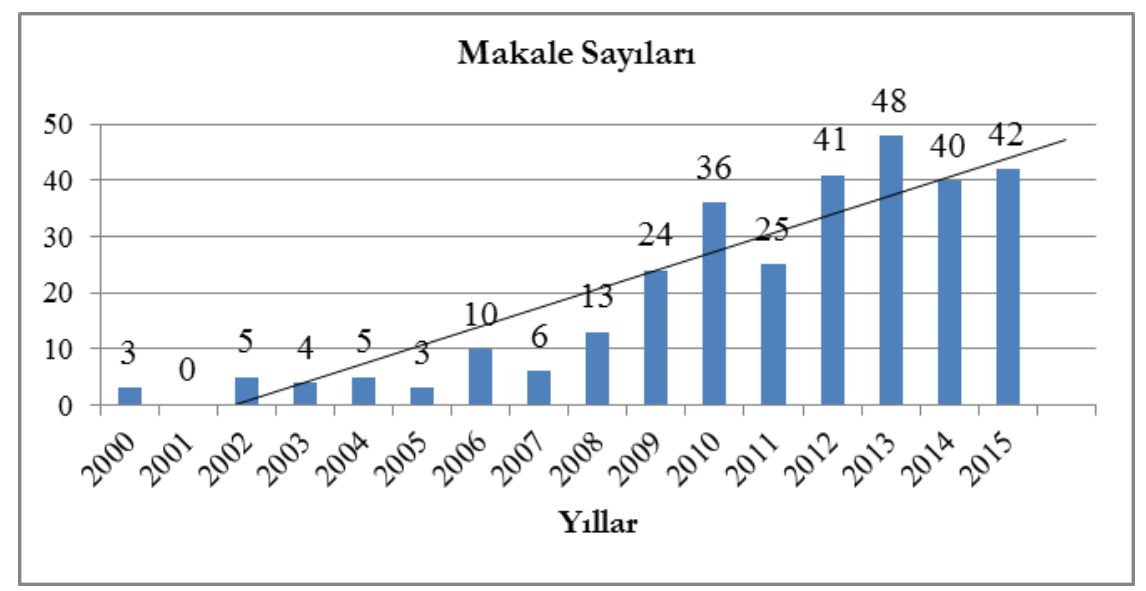

\section{Sonuç}

İnternetin ve akıllı telefonların hayatlarımızda önemli bir yer kazanması, 1940’lardan beri çalısıllan ve 1967 yilında ilk defa Arndt (1967) tarafindan tanımlanan AAİLT sürecinde değişiklikler yaratmıştır. AAİLT’de artık internet tabanlı platformlar aracillğı ile iletişim elektronikleşmiş, diğer bir ifade ile geleneksel AAİLT yerini E-AAİLT’e bırakmıştır. Bu iki iletişim türü arasında mesaj göndericiler, mesaj alıcılar ve aracı kaynak açısından önemli farklılıklar görülmektedir. Aslında bu farklılıkların, iletişimin doğrudan sözlü olarak değil de internet tabanlı platformlar aracıllı̆ı ile çoğu zaman yazılı olarak yapılıyor olmasından kaynaklandığı düşünülmektedir. Aracı olarak internet tabanlı platformların kullanilması ile E-AAİLT'de, geleneksel AAİLT'deki gibi mesaj göndericiler ile alıcılar arasında samimi bir ilişkiye gerek kalmamakta ve kişiler, artık internet başından kimliklerini açıklamadan takma isimler ile hiç tanımadıkları sayısız kişiye düşüncelerini aktarabilmektedirler.

Literatürde bu konu "elektronik ağızdan ağıza iletişim" kelime grubu ile ifade edilmiş olsa da Tablo 2'den görüldüğü üzere, literatür taramasından en fazla sayıda makaleye "online ağızdan ağıza iletişim" arama ölçütü ile erişilmiştir. Diğer bir ifade ile bu konu ile ilgili en fazla çalışmayı kapsayan arama ölçütü "online ağızdan ağıza iletişim" dir. Gelecekte bu konuya dair çalışma yapmayı planlayan araştırmacilara, öncelikli olarak "online ağızdan ağıza iletişim" arama ölçütü ile tarama yapmaları sonrasında ise "online yorum", "online tavsiye" ve "elektronik ağızdan ağıza iletişim" kelime gruplarını arama ölçütü olarak kullanmaları tavsiye edilebilir. 
Bu konunun ilk olarak 2000 yllında araştırmacılar tarafından çalışıldığı görülmektedir. Yıllar içinde bu konu hızla önem kazanmaya ve çalışılmaya başlanmıştır. Buna sebep olarak internetin yaygınlaşması ve internet üzerinden yapılan alışverişler ile yorum yazmaya yönelik web sitelerindeki artış gösterilebilir. Konu ile ilgili 2008 yilından sonra yapılan çalışmaların sayısındaki önemli artış ise akıllı telefonların kullanımındaki yaygınlık ile ilişkilendirilebilir. Akıllı telefonların yaygınlaşması ile kişiler günümüzde artık çok kolay yorum yazabilmekte ve başkalarının ürün ya da hizmetlere yönelik düşüncelerine rahatlıkla erişebilmektedirler. Böylece, online yorumlar eskisine oranla artık daha fazla kişinin hayatına daha fazla zaman alarak girmeye başlamış ve bu da araştırmacıların dikkatini çekmiş olabilir. Bu konu ile ilgili olarak araştırmacılar, akıllı telefonların da yaygınlaşmasının E-AAİLT sürecinde yeni farklılıklar doğurup doğurmadığını; geleneksel AAİLT ve EAAİLT'den sonra "Mobil Ağızdan Ağıza İletişim (M-AAİLT)" olarak isimlendirilecek yeni bir iletişim formunun ortaya çıkıp çıkmadığını araştırabilirler. Çünkü artık, kişilerin, ürün, hizmet ya da firmalar ile ilgili kullanıcı yorumlarına ulaşmaları çok kolaylaşmıştır. Benzer şekilde tüketiciler de istedikleri zaman ve mekanda, hem online yorum yazabilmekte hem de başkalarının yorumlarını okuyabilmektedirler.

Pazarlama alanında en iyi olduğu düşünülen 24 dergi arasında, bu konu ile ilgili yapılan çalışmaların en fazla yer aldığı dergilerin sırasıyla, "Journal of Interactive Marketing", "Journal of Business Research" ve "Marketing Science" olduğu görülmektedir. Bu dergileri ise "European Journal of Marketing", "Journal of Marketing Research" ve "Psychology \& Marketing" dergileri takip etmektedir. Bu konu ile ilgili çalışan ve yayın yapacak olan araştırmacılara, bu çalışmanın sonuçlarının dergi belirleme aşamasında yardımc1 olacağı düşünülmektedir. Bu araştırmada, konunun pazarlama alanındaki önemine vurgu yapmak için sadece pazarlama alanında en iyi olduğu düşünülen dergilere odaklanılmıştır. Ancak, bu dergilere ek olarak, işletme, yönetim ve iletişim dergileri de araştırmaya dahil edilerek daha geniş ölçekte daha genellenebilir sonuçlar elde edilebilir. Ayrıca, belirlenen 24 dergi dışında da bu çalışmaya dahil edilmeyen ancak konu ile ilgili önemli çalışmaların yer aldığı pazarlama alanından dergiler gözden kaçırılmış olabilir. Sonraki çalışmalarda farklı kriterler ile daha kapsamlı literatür araştırmaları yapilabilir. 


\section{Kaynakça}

Alexandrov, A., Lilly, B., ve Babakus, E. (2013). The effects of social-and self-motives on the intentions to share positive and negative word of mouth. Journal of the Academy of Marketing Science, 41(5), 531-546.

Arndt, J. (1967). Role of product-related conversations in the diffusion of a new product. Journal of Marketing Research, 4(3), 291-295.

Balagué, C. ve De Valck, K. (2013). Using blogs to solicit consumer feedback: The role of directive questioning versus no questioning. Journal of Interactive Marketing, 27(1), 62-73.

Baldus, B. J., Voorhees, C., ve Calantone, R. (2015). Online brand community engagement: Scale development and validation. Joumal of Business Research, 68(5), 978-985.

Bansal, H. S. ve Voyer, P. A. (2000). Word-of-mouth processes within a services purchase decision context. Journal of Service Research, 3(2), 166-177.

Benedicktus, R. L., Brady, M. K., Darke, P. R., ve Voorhees, C. M. (2010). Conveying trustworthiness to online consumers: Reactions to consensus, physical store presence, brand familiarity, and generalized suspicion. Journal of Retailing, 86(4), 322-335.

Berger, J. (2014). Word of mouth and interpersonal communication: A review and directions for future research. Journal of Consumer Psychology , 24(4), 586-607.

Berger, J. ve Schwartz, E. M. (2011). What drives immediate and ongoing word of mouth? Journal of Marketing Research, 48(5), 869-880.

Bone, P. F. (1995). Word-of-mouth effects on short-term and long-term product judgments. Journal of Business Research, 32(3), 213-223.

Brown, J. J. ve Reingen, P. H. (1987). Social ties and word-of-mouth referral behavior. Journal of Consumer Research, 14(3), 350-362.

Bughin, J., Doogan, J., ve Vetvik, O. (2010). A new way to measure wordof-mouth marketing. McKinsey Quarterly, 2, 113-116.

Chatterjee, P. (2001). Online Reviews - Do Consumers Use Them? ACR 2001 Proceedings, (s. 129-134). Provo, Utah.

Chevalier, J. A. ve Mayzlin, D. (2006). The effect of word of mouth on sales: Online book reviews. Journal of Marketing Research, 43(3), 345-354.

Chintagunta, P. K., Gopinath, S., ve Venkataraman, S. (2010). The effects of online user reviews on movie box office performance: Accounting 
for sequential rollout and aggregation across local markets. Marketing Science, 29(5), 944-957.

Christodoulides, G., Michaelidou, N., ve Argyriou, E. (2012). Cross-national differences in e-WOM influence. European Journal of Marketing, 46(11/12), 1689-1707.

Day, G. (1971). Attitude change, media and word of mouth. Journal of Advertising Research., 11(6), 31-40.

De Matos, C. A. ve Rossi, C. A. (2008). Word-of-mouth communications in marketing: a meta-analytic review of the antecedents and moderators. Journal of the Academy of Marketing Science, 36(4), 578596.

De Matos, C. A., Vieira, V. A., ve Veiga, R. T. (2012). Behavioural responses to service encounter involving failure and recovery: the influence of contextual factors. The Service Industries Journal, 32(14), 22032217.

De Vries, L., Gensler, S., ve Leeflang, P. S. (2012). Popularity of brand posts on brand fan pages: An investigation of the effects of social media marketing. Journal of Interactive Marketing, 26(2), 83-91.

Decker, R. ve Trusov, M. (2010). Estimating aggregate consumer preferences from online product reviews. International Journal of Research in Marketing, 27(4), 293-307.

Dellarocas, C. (2003). The digitization of word of mouth: Promise and challenges of online feedback mechanisms. Management Science, 49(10), 1407-1424.

Dichter, E. (1966). How word-of-mouth advertising works. Harvard Business Review , 44(6), 147-160.

Duan, W., Gu, B., ve Whinston, A. B. (2008). The dynamics of online wordof-mouth and product sales-An empirical investigation of the movie industry. Journal of Retailing, 84(2), 233-242.

Fong, J. ve Burton, S. (2008). A cross-cultural comparison of electronic word-of-mouth and country-of-origin effects. Journal of Business Research, 61(3), 233-242.

Gebauer, J., Füller, J., ve Pezzei, R. (2013). The dark and the bright side of co-creation: Triggers of member behavior in online innovation communities. Journal of Business Research, 66(9), 1516-1527. 
Gershoff, A., Mukherjee, A., ve Mukhopadhyay, A. (2003). Consumer acceptance of online agent advice: Extremity and positivity effects. Journal of Consumer Psychology, 13(1/2), 161-170.

Gounaris, S., Dimitriadis, S., ve Stathakopoulos, V. (2010). An examination of the effects of service quality and satisfaction on customers' behavioral intentions in e-shopping. Journal of Services Marketing, 24(2), 142-156.

Gupta, P. ve Harris, J. (2010). How e-WOM recommendations influence product consideration and quality of choice: A motivation to process information perspective. Journal of Business Research, 63(9), 1041-1049.

Harrison-Walker, L. (2001). The measurement of word-of-mouth communication and an investigation of service quality and customer commitment as potential antecedents. Journal of Service Research, 4(1), 60-75.

Häubl, G. ve Trifts, V. (2000). Consumer decision making in online shopping environments: The effects of interactive decision aids. Marketing Science, 19(1), 4-21.

Hennig-Thurau, T., Gwinner, K. P., Walsh, G., ve Gremler, D. D. (2004). Electronic word-of-mouth via consumer-opinion platforms: What motivates consumers to articulate themselves on the Internet? Journal of Interactive Marketing, 18(1), 38-52.

Herr, P. M., Kardes, F. R., ve Kim, J. (1991). Effects of word-of-mouth and product-attribute information on persuasion: An accessibilitydiagnosticity perspective. Journal of Consumer Research, 17(4), 454462.

Ho-Dac, N. N., Carson, S. J., ve Moore, W. L. (2013). The effects of positive and negative online customer reviews: do brand strength and category maturity matter? Journal of Marketing, 77(6), 37-53.

Hsu, L. C., Wang, K. Y., ve Chih, W. H. (2013). Effects of web site characteristics on customer loyalty in B2B e-commerce: evidence from Taiwan. The Service Industries Joumal, 33(11), 1026-1050.

Huang, P., Lurie, N. H., ve Mitra, S. (2009). Searching for experience on the web: an empirical examination of consumer behavior for search and experience goods. Journal of Marketing, 73(2), 55-69.

Huggins, K. A., Holloway, B. B., ve White, D. W. (2013). Cross-cultural effects in E-retailing: The moderating role of cultural confinement 
in differentiating Mexican from non-Mexican Hispanic consumers. Journal of Business Research, 66(3), 321-327.

Karakaya, F. ve Ganim Barnes, N. (2010). Impact of online reviews of customer care experience on brand or company selection. Journal of Consumer Marketing, 27(5), 447-457.

Katz, E. ve Lazarsfeld, P. (1955). Personal influence: The part played by people in the flow of mass communication. Glencoe: The Free Press.

King, R. A., Racherla, P., ve Bush, V. D. (2014). What we know and don't know about online word-of-mouth: A review and synthesis of the literature. Journal of Interactive Marketing, 28(3), 167-183.

Kotler, P. ve Keller, K. (2012). Marketing Management (Global b.). Pearson.

Kulkarni, G., Ratchford, B. T., ve Kannan, P. K. (2012). The impact of online and offline information sources on automobile choice behavior. Journal of Interactive Marketing, 26(3), 167-175.

Lau, G. ve Ng, S. (2001). Individual and situational factors influencing negative word-of-mouth behaviour. Canadian Journal of Administrative Sciences, 18(3), 163-178.

Lee, T. Y. ve Bradlow, E. T. (2011). Automated marketing research using online customer reviews. Journal of Marketing Research, 48(5), 881894.

Lin, H. H., Wang, Y. S., ve Chang, L. K. (2011). Consumer responses to online retailer's service recovery after a service failure: A perspective of justice theory. Managing Service Quality: $A n$ International Journal, 21(5), 511-534.

López, M. ve Sicilia, M. (2014). Determinants of E-WOM influence: The role of consumers internet experience. Journal of Theoretical and Applied Electronic Commerce Research, 9(1), 28-43.

Lovett, M. J., Peres, R., ve Shachar, R. (2013). On brands and word of mouth. Journal of Marketing Research, 50(4), 427-444.

Mayzlin, D. (2006). Promotional chat on the Internet. Marketing Science, 25(2), 155-163.

Netzer, O., Feldman, R., Goldenberg, J., ve Fresko, M. (2012). Mine your own business: Market-structure surveillance through text mining. Marketing Science, 31(3), 521-543.

Park, C., ve Lee, T. M. (2009). Information direction, website reputation and eWOM effect: A moderating role of product type. Journal of Business Research, 62(1), 61-67. 
Park, D. H., Lee, J., ve Han, I. (2007). The effect of on-line consumer reviews on consumer purchasing intention: The moderating role of involvement. International Journal of Electronic Commerce, 11(4), 125148.

Parthasarathy, M. ve Forlani, D. (2010). Do satisfied customers bad-mouth innovative products? Psychology \& Marketing, 27(12), 1134-1153.

Schamari, J., ve Schaefers, T. (2015). Leaving the home turf: How brands can use webcare on consumer-generated platforms to increase positive consumer engagement. Journal of Interactive Marketing, 30, 20-33.

Senecal, S. veNantel, J. (2004). The influence of online product recommendations on consumers' online choices. Journal of Retailing, 80(2), 159-169.

Senecal, S., Kalczynski, P. J., ve Nantel, J. (2005). Consumers' decisionmaking process and their online shopping behavior: a clickstream analysis. Journal of Business Research, 58(11), 1599-1608.

Steffes, E. M. ve Burgee, L. E. (2009). Social ties and online word of mouth. Internet Research, 19(1), 42-59.

Sundaram, D., Mitra, K., ve Webster, C. (1998). Word-of-mouth communications: A motivational analysis. $N A$-Advances in Consumer Research, 25.

Teichmann, K., Stokburger-Sauer, N. E., Plank, A., ve Strobl, A. (2015). Motivational Drivers of Content Contribution to Company-Versus Consumer-Hosted Online Communities. Psychology \& Marketing, 32(3), 341-355.

Tsang, A. S. ve Prendergast, G. (2009). Does culture affect evaluation expressions? A cross-cultural analysis of Chinese and American computer game reviews. European Journal of Marketing, 43(5/6), 686707.

Van Laer, T. ve De Ruyter, K. (2010). In stories we trust: How narrative apologies provide cover for competitive vulnerability after integrity-violating blog posts. International Journal of Research in Marketing, 27(2), 164-174.

Van Noort, G. ve Willemsen, L. M. (2012). Online damage control: The effects of proactive versus reactive webcare interventions in consumer-generated and brand-generated platforms. Journal of Interactive Marketing, 26(3), 131-140. 
Wang, X. (2011). The effect of inconsistent word-of-mouth during the service encounter. Journal of Services Marketing, 25(4), 252-259.

Watts, D. ve Dodds, P. (2007). Influentials, networks, and public opinion formation. Journal of Consumer Research , 34(4), 441-458.

Westbrook, R. (1987). Product/consumption-based affective responses and postpurchase processes. Journal of Marketing Research, 24(3), 258270.

Xiong, G. ve Bharadwaj, S. (2014). Prerelease buzz evolution patterns and new product performance. Marketing Science, 33(3), 401-421.

Yadav, M. S. ve Pavlou, P. A. (2014). Marketing in computer-mediated environments: Research synthesis and new directions. Journal of Marketing, 78(1), 20-40.

Yun, G. W., Park, S. Y., ve Ha, L. (2008). Influence of cultural dimensions on online interactive review feature implementations: A comparison of Korean and US retail web sites. Journal of Interactive Marketing, 22(3), 40-50.

Zhao, Y., Yang, S., Narayan, V., ve Zhao, Y. (2013). Modeling consumer learning from online product reviews. Marketing Science, 32(1), 153169.

Zhu, F. ve Zhang, X. (2010). Impact of online consumer reviews on sales: The moderating role of product and consumer characteristics. Journal of Marketing, 74(2), 133-148. 